\title{
Novos Caminbos da Linguística Textual: reflexões teóricas sobre o conceito de tradições discursivas e os estudos diacrônicos no português paulista a partir de alguns gêneros impressos do século XIX e XX
}

\author{
Maria Lúcia da Cunha Victorio de Oliveira Andrade \\ Fabio Fernando Lima ${ }^{2}$ \\ Kelly Cristina de Oliveira ${ }^{3}$ \\ Paulo Roberto Gonçalves Segundo ${ }^{4}$ \\ Rafaela Baracat Ribeiro
}

\begin{abstract}
RESUMO: O presente artigo tem como objetivo discutir o conceito de tradições discursivas e apresentar parte das pesquisas que vêm sendo desenvolvidas pelos integrantes do PHPP dentro do subprojeto "Tradições discursivas: constituição e mudança dos gêneros numa perspectiva diacrônica".
\end{abstract}

Palavras-chave: tradições discursivas; cartas do leitor; notícia; editorial; gênero discursivo.

ABSTRACT: This paper aims to discuss the concept of discourse traditions and to show some of the research being developed by members of the subproject within PHPP entitled "Discourse traditions: constitution and change of genre from a diachronic perspective".

Keywords: discourse traditions; readers' letters; news; editorial; discourse genres.

Professora da Área de Filologia e Língua Portuguesa - FFLCH-USP e Coordenadora do Subgrupo Tradições discursivas: constituição e mudança dos gêneros discursivos numa perspectiva diacrônica. E-mail: maluvictorio@uol.com.com.br

2 Pesquisador de pós-doutorado da Área de Filologia e Língua Portuguesa - FFLCH-USP e bolsista FAPESP (proc.09/54845-6).E-mail: fabiofernando@uol.com.br

3 Doutoranda da Área de Filologia e Língua Portuguesa - FFLCH-USP e bolsista CAPES. E-mail: kelly_cristina_oli@yahoo.com.br

4 Doutorando da Área de Filologia e Língua Portuguesa - FFLCH-USP e bolsista CAPES. E-mail: paulosegundo@uol.com.br

5 Mestranda da Área de Filologia e Língua Portuguesa - FFLCH-USP e bolsista FAPESP (proc. 08/55873-0). E-mail: rafaela.baracat@gmail.com 


\section{Introdução}

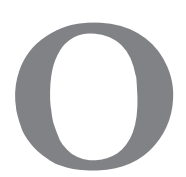

conceito de tradições discursivas, nascido no âmbito da Linguística Textual alemã e, de modo especial, dentro da Linguística Românica, dá suporte para investigar como se constituíram os textos que circulavam e circulam através dos tempos, em diferentes esferas sociais, revelando práticas sócio-históricas de uso da linguagem. Recentemente, esse conceito vem sendo utilizado como suporte teórico-metodológico pelos pesquisadores do Projeto História do Português Paulista e, de modo particular, pelos integrantes do subgrupo "Tradições discursivas: constituição e mudança dos gêneros discursivos numa perspectiva diacrônica".

Fortemente influenciados pela tradição da escola de Eugênio Coseriu, os linguistas alemães fundamentam-se na distinção de três níveis do falar, ou seja, três aspectos da atividade linguística cuja diferença é considerada imprescindível para qualquer questão do estudo da linguagem. Trata-se da distinção entre o nível universal de falar em geral (primeiro nível), comum a todos os seres humanos; o segundo nível é o histórico, relativo às línguas como sistemas de significação historicamente dados, atualizados; e, em terceiro nível, os textos ou discursos concretos.

A partir dessa perspectiva, o conceito de Tradições Discursivas (TD) foi proposto por Peter Koch (1997), depois foi retomado por Oesterreicher $(1997,2001,2002)$ e, mais recentemente, foi tratado por Kabatek (2001, 2003 e 2006). Os autores consideram que os textos são portadores de tradições, isto é, apresentam regularidades discursivas ou formas textuais já produzidas pela sociedade, em momentos anteriores, que permaneceram ou se modificaram ao longo de sua existência. Essas regularidades configuram, em linhas gerais, a concepção do que se denomina TD.

Buscando situar as TD na teoria linguística, com base na proposta de Coseriu (1988), Oesterreicher (2001) relaciona os diferentes níveis da linguagem com os conceitos de fala e escrita. Ao nivel universal, corresponde o falar entendido em seu sentido geral, como "atividade universal genericamente humana". Nessa atividade, as práticas orais e escritas seguem as exigências da imediatez ou da distância comunicativas entre os falantes, que permitem identificar diferentes TD típicas da oralidade e da escrita.

Corresponde, por sua vez, ao nivel histórico, a língua instituída social e sistematicamente. Para Oesterreicher, nesse nível, encontram-se: a atividade do falar de acordo com uma dada tradição histórica e as línguas históricas 
particulares com suas variedades faladas e escritas. Trata-se, portanto, da duplicação do nível histórico coseriano para o acréscimo das TD nesse plano (cf. Kabatek, 2003, 2004). Situadas nesse domínio, na visão de Oesterreicher, as TD abarcam os modelos tradicionais de realização dos gêneros literários e não literários, bem como dos tipos textuais, na medida em que as concebe como quaisquer produções comunicativas estabelecidas dentro de grandes domínios discursivos (técnico, filosófico, teológico, militar, científico etc.), determinadas por coordenadas históricas e sociais.

Finalmente, ao nivel individual, corresponde a concretização da fala ou da escrita em uma determinada situação de produção, isto é, a atividade do falar propriamente dita ou, ainda, a atualização do discurso individual.

Considerando a relação entre esses níveis da linguagem e as manifestações linguísticas, faz-se necessário estabelecer uma diferenciação entre a historicidade da língua e a historicidade da TD, pois, segundo Kabatek (2004: 160), não é consenso entre os romanistas alemães "sobre onde verdadeiramente as TD devam ser alocadas na teoria da linguagem". Há uma corrente que postula a duplicação dos três níveis; contudo, a mais difundida inclui as TD no nível histórico, enquanto a outra as enquadra no nível individual.

Ao passo que a historicidade das TD diz respeito às manifestações culturais e linguísticas/os textos concretos que estabelecem uma relação de tradição com modelos textuais anteriormente realizados, a historicidade da língua refere-se à historicidade do próprio homem, na medida em que é um sujeito histórico pertencente a uma comunidade na qual são difundidos valores, saberes e crenças.

A língua tem, por sua vez, caráter a-histórico. Ela cria e recria, numa sucessão infinita, atos que não têm um princípio delimitável. Por seu turno, as TD têm caráter histórico, pois, como qualquer outra tradição cultural, são “delimitáveis no eixo temporal" (Kabatek, 2001: 103).

Dada essa historicidade, Kabatek (2006: 512) entende por TD "a repetição de um texto ou de uma forma textual ou de um modo particular de escrever ou falar que adquire valor de signo próprio". O autor afirma que o falante escolhe, num primeiro momento, no acervo linguístico, formas de falar ou de escrever presentes na memória cultural de uma sociedade. Em seguida, filtra sua produção linguística por meio das TD que lhe fornecerão o gênero discursivo adequado ao seu propósito comunicativo. Kabatek esclarece que esse processo refere-se a qualquer finalidade comunicativa encapsulada 
em formas de expressão, tais como: saudação, agradecimento, reclamação, instauradas em quaisquer meios de comunicação.

Para o referido pesquisador, as TD podem adaptar-se, em princípio, em qualquer variedade, bem como dar origem a uma nova tradição e ser aceita e adaptada pela comunidade. Nessa perspectiva,

$$
\begin{aligned}
& \text { [...] uma primeira abordagem poderia entender as TD como modos tradicio- } \\
& \text { nais de dizer as coisas, modos que podem ir desde uma fórmula simples até } \\
& \text { um gênero ou uma forma literária complexa. Agora, precisamente por essa } \\
& \text { relação entre as TD e os gêneros, tem-se entendido em alguns trabalhos como } \\
& \text { sinônima a noção de TD com a de gênero. Mas se fosse assim, o próprio } \\
& \text { termo TD não seria mais do que um substituto para algo já estudado à exaustão } \\
& \text { pela linguística de texto (Kabatek, 2006: 509). }
\end{aligned}
$$

Em outras palavras, podemos dizer que toda produção textual requer o conhecimento, por parte dos usuários da língua, de modelos de realizações discursivas (orais ou escritas) anteriormente produzidos pela sociedade, denominados tradições discursivas. Tais modelos revelam a recorrência a certas fórmulas, atos de fala, estilos, que estabelecem, na construção de um texto ou discurso, uma relação entre o momento atual e a tradição.

O estudo desses modelos discursivos gerais, que guiam o discurso individual, parte da convergência entre os estudos da Pragmática e da Linguística Histórica, bem como de uma proposta de Análise do Discurso realizada sob um viés diacrônico.

A relação essencial entre o estudo pragmático e a diacronia linguística é enfatizada por Brigitte Schlieben-Lange, em obra de 1983, onde apresenta a proposta de uma Pragmática Histórica, para ressaltar que o percurso histórico das línguas não é independente do percurso histórico dos textos e de seu contexto social. Do mesmo modo, Schmidt-Riese (2002) procura delimitar os procedimentos metodológicos de uma Análise do Discurso realizada segundo a perspectiva histórica, observando os textos a partir de uma perspectiva diacrônica.

Para Schmidt-Riese (2002: 15-17), no estudo dos textos históricos, é preciso que sejam levadas em consideração as realidades linguísticas e nãolinguísticas. A proposta da autora tem por base a concepção teórica de Foucault (1966, 1969), para quem o discurso equivale às "condições do falar sobre entidades potencialmente, mas não necessariamente coincidentes com determinadas práticas sociais", assim como às condições e circunstâncias que subjazem 
às mesmas práticas, consideradas segundo os diversos setores da atividade social.

Para além dos estudos filológicos, é preciso levar em conta também a perspectiva sociológica, segundo a qual o falar é uma atividade social relacionada à representação da realidade. Nessa perspectiva, ao considerar a documentação escrita preservada como discurso histórico, Schmidt-Riese observa a importância das condições de produção relativas ao contexto de época de cada documento.

Os textos conservados pela escrita auxiliam na reconstrução do momento histórico e permitem recuperar as formas de pensar de um período a partir de sua produção textual (Brandão, Andrade e Aquino, 2009). Tais aspectos apontam para significativas contribuições que a Análise do Discurso pode trazer às demais áreas das ciências humanas, a partir da observação e análise atenta dos escritos de época.

Cabe, dessa forma, destacar que o princípio universal de existência de modelos discursivos é decorrente do fato de que as tradições discursivas são transferiveis de uma língua para outra, conforme afirma Kabatek (2003). A interferência entre as línguas permite a troca de aspectos discursivos e culturais, levando a processos de inovação linguística, na medida em que a adoção de novas tradições discursivas (interferência positiva) implica novas criações linguísticas. O pesquisador aponta ainda sobre a possibilidade de haver uma interferência negativa entre as línguas, na qual não ocorre adoção, mas sim ausência ou rechaço de elementos linguísticos.

Além de estarem relacionadas à possibilidade de transferência de elementos discursivos entre as línguas, as tradições discursivas estão ligadas às questões de economia linguística e de intertextualidade, pelo fato de ser "mais econômico repetir um esquema textual guardado na memória que criar um texto totalmente novo" e porque, em todo modelo textual que se repete, é estabelecida "uma relação entre o texto e outros textos já ditos ou escritos" (Kabatek, 2003: 4-5).

É preciso destacar que as TD, pertencentes ao âmbito da linguagem, apresentam as mesmas características que outra tradição cultural qualquer, configurando-se a partir da relação entre os sujeitos históricos e o mundo no qual eles se inserem e constroem. Essa perspectiva indica como aspectos socioculturais e linguísticos estão entrelaçados, pois se observa na sociedade, por um lado, que existem épocas da história que são mais conservadoras quanto 
à introdução de novas tradições discursivas em decorrência de fatores sóciohistóricos. Por outro lado, há épocas que se mostram mais inovadoras e revolucionárias com relação à adoção de um novo modelo textual, de acordo com Kabatek (2003).

Ao partir da concepção de que os textos se organizam e são regidos por modelos tradicionais de realização discursiva, é preciso observar as características fixas presentes na estruturação formal dos textos. Torna-se necessário considerar, portanto, a existência de um conjunto de traços estilísticos e esquemas textuais convencionais que constituem os gêneros discursivos.

Todo texto efetiva-se a partir da materialização de um gênero discursivo e segue as coerções determinadas por esse gênero, para que a interação possa ser estabelecida adequadamente. Esse processo demanda o reconhecimento, o emprego e a transmissão de modelos discursivos ao longo do tempo que permitem, portanto, a manutenção de características básicas, sem que se descartem as eventuais necessidades de adequação aos contextos de cada momento histórico.

Esse conjunto de traços que são transmitidos pelas sucessivas gerações de usuários que falam e escrevem (as tradições discursivas) definem a unidade e a especificidade dos gêneros discursivos, mediante a utilização de conteúdos temáticos e de esquemas textuais na esfera das superestruturas de organização linguístico-discursivas que são pertinentes à configuração contextual dos gêneros.

Segundo Gomes (2005), motivadas pelos fatores sócio-históricos, que estão presentes na base de toda e qualquer atividade interacional, as TD podem mudar ao longo do tempo. Entretanto, elas são constituídas em função da permanência de traços que garantem a continuidade de um gênero discursivo ao longo da sua trajetória, possibilitando o reconhecimento e a identificação das formas veiculadas em diferentes épocas.

O estudo do gênero discursivo torna-se mais rico mediante o conhecimento dos processos de sua formação histórica, da qual fazem parte da sua configuração certas tradições que o constituem ao longo do tempo e que possibilitam a comunicação eficiente entre os indivíduos de uma determinada comunidade ou grupo social.

Assim, as pesquisas a respeito das TD revelam-se essenciais para os trabalhos de elaboração de corpora diacrônicos de análise linguística e para a organização de tipologias textuais. Como observa Gomes (2005: 87), tais estudos possibilitam o estabelecimento de diversas relações entre os domínios 
textual (relativo ao uso) e linguístico (relativo ao sistema), bem como estão intimamente ligados ao movimento histórico de mudança linguística.

Nesse sentido, conforme evidenciam diversas pesquisas recentemente desenvolvidas, principalmente no âmbito dos estudos da Romanística alemã, o estudo comparativo de documentos pertencentes a épocas distintas pode revelar a ocorrência de mudanças não só gramaticais, como também mudanças discursivas, relacionadas à própria constituição do gênero discursivo.

Neste artigo, produzido por cinco pesquisadores do PHPP do subprojeto de TD, tem-se como objetivo apresentar parte do que vem sendo desenvolvido pelos integrantes do grupo no que se refere aos textos jornalísticos impressos.

\section{Cartas do editor}

Em pesquisa realizada no âmbito do subgrupo referido neste artigo, realiza-se um estudo diacrônico a respeito das cartas de editor ${ }^{6}$ na imprensa paulista, representada por três jornais dos séculos XIX e XX - O Farol Paulistano, Correio Paulistano e A Provincia de S. Paulo/ O Estado de S. Paulo. Nessa pesquisa, procede-se a uma verificação dos elementos constitutivos e das regularidades discursivas encontradas nesse gênero ao longo do período em questão?

Para tanto, busca-se na concepção das TD o suporte para a análise dos traços de permanência e dos indícios de mudança na trajetória do gênero discursivo focalizado. Com isso, visa-se contribuir para as questões relacionadas à história desse gênero jornalístico, cuja abordagem pode favorecer o estudo do gênero e de suas marcas linguísticas na realização atual, conforme aponta Zavam (2009).

Assim, nesta seção, serão destacadas as influências que o gênero carta do editor teria recebido de outros gêneros produzidos no jornal, bem como do desenvolvimento social, econômico e tecnológico. Ao tratar do percurso da mídia impressa, os estudos de Rizzini $(1968 ; 1988)$ apontam que a

6 Pesquisa de Rafaela Baracat Ribeiro (2011), intitulada Tradições discursivas e modalidade no gênero carta do editor de jornais paulistas do século XIX ao início do século XX, sob orientação da Profa. Dra. Maria Lúcia da Cunha Victório de Oliveira Andrade.

7 Antecipa-se, neste item, pontos desenvolvidos na dissertação de mestrado de Ribeiro, defendida em março de 2011. 
carta $^{8}$ serviu de base para as gazetas manuscritas e à gazeta impressa, dada a sua circularidade, periodicidade e informatividade. Devido a essas características, o autor sustenta que a função das cartas era a mesma de um jornal, uma vez que cópias de cartas e relatórios oficiais garantiam a divulgação dos assuntos de dentro e fora das comunidades onde esses textos circulavam.

Mesmo com a criação da tipografia no século XV, até o fim do século XVIII ainda era intensa a circulação de cartas e jornais manuscritos, pois, de acordo com Rizzini (1988), a correspondência, além de propagar as novidades, escapava da censura com mais facilidade. Desse modo, essas cartas, posteriormente à fase da gazeta manuscrita e na etapa impressa, passaram a ser reconhecidas como folhas volantes, folhas avulsas ou papéis de notícias.

Decorrido o processo de constituição e estabelecimento do jornalismo, particularmente, no século XIX, no âmbito da imprensa brasileira, evidencia-se que os jornais eram feitos de artigos marcadamente opinativos, não havendo uma separação clara entre informação e opinião. Desses artigos, destacam-se os chamados artigos de fundo ${ }^{9}$ que apresentavam maior engajamento social que os demais textos do jornal, conforme aponta Bahia (1990). Segundo o autor, no período do Império e da Primeira República, o artigo de fundo é "pesado, solene, eloquente como o discurso parlamentar e (...) geralmente ocupa o espaço nobre da primeira página ou da terceira página" (p.100).

Traços dessa linguagem veemente, incisiva e panfletária do artigo de fundo também são reconhecíveis nas cartas de redator de O Farol Paulistano, o primeiro jornal impresso paulista. Na pesquisa mencionada, verifica-se pela linguagem empregada que as cartas de redator desse jornal apresentam certo grau de panfletagem, na medida em que elas são constituídas por textos contundentes e doutrinários cuja função é satirizar, polemizar e denunciar figuras públicas ou acontecimentos de ordem social e política.

Ao passo que se observam as semelhanças entre um e outro aspecto dos textos, verifica-se TD sendo retomadas na configuração dos gêneros. Assim, o conteúdo político, crítico e contestador de fatos ocorridos na socie-

8 Para Bazerman (2006: 83), a carta, em contextos específicos, "parece ser um meio flexível no qual muitas das funções, relações e práticas institucionais podem se desenvolver tornando novos usos socialmente inteligíveis, enquanto permite que a forma de comunicação caminhe em novas direções".

9 Texto que publica a opinião do jornal, podendo ser assinado ou não. Equivale ao editorial. (Cf. Erbolato, 1985) 
dade pode ser encontrado não só nas cartas do redator do século XIX. O alto grau de criticidade já era característico das cartas/folhas volantes e dos panfletos ${ }^{10}$ e pasquins ${ }^{11}$, que, por sua vez, também teriam influenciado os artigos opinativos produzidos nos jornais.

Considera-se que na produção desses gêneros (cartas, panfletos, artigos) exista uma confluência de TD, particularmente em relação à finalidade discursiva na medida em que parecem partilhar de um mesmo propósito comunicativo. Isso se fundamenta na concepção de que os gêneros discursivos não são inovações absolutas, conforme afirma Marcuschi (2002), mas apresentam ancoragem em outros já existentes.

Além desses aspectos, destaca-se a influência do desenvolvimento histórico-tecnológico nas práticas sociais. Para Zavam, (2009: 3), "uma mudança nas condições de produção acarreta inevitavelmente mudanças nos gêneros". Em fins do século XIX e início do XX, ocorreram alterações significativas na imprensa, que passa de uma fase artesanal para uma fase industrial, cujos interesses institucionais passam a sobrepor as questões político-partidárias intensificadas no jornalismo novecentista.

Devido à consolidação da nova imprensa de negócios, "o editor brasileiro não poderia escapar à evolução empresarial” (cf. Beltrão, 1980:49). Com a reformulação técnica e a divisão industrial pela qual passa a redação jornalística, quando é iniciado o sistema de editores, a sessão opinativa passa a ganhar especificidades que darão novas facetas aos textos produzidos nesse espaço (cf. Bahia, 1990).

Segundo Bahia (2009), a partir das inovações realizadas na redação jornalística, ocorre a separação definitiva entre a notícia e os textos opinativos, sendo reservado um espaço próprio para apresentação da opinião e da linha ideológica do posicionamento de um meio de comunicação. Nesse processo, o autor cita a alteração do artigo de fundo pelo editorial.

Sem que se mude basicamente a natureza, dando-lhe, porém, outro caráter, "o editorial remove os vincos personalistas e agressivos procedentes

10 Escrito de pequena extensão, satírico ou polêmico em estilo veemente. O termo teve origem no inglês pamphlet, o qual se refere ao nome popular de certa comédia latina do século XII, denominada Pamphilus seu de Amore, muito conhecida por causa da personagem representativa de velha alcoviteira (cf. Machado, 1990).

11 "Folheto de linguagem livre, anárquica, de periodicidade incerta e teor ardoroso de ataques pessoais" (cf. Gomes, 2007: 77). 
do artigo de fundo, e atenua o tom contundente para em seu lugar estabelecer padrões de objetividade e racionalidade. Um novo estilo e uma nova linguagem atualizam a opinião com o editorial" (Bahia, 1990: 103-4). No curso desse processo de renovação, o artigo de fundo, que teria herdado traços do panfleto, porém retirando seus exageros, "lega ao editorial uma copiosa e exemplar tradição crítica", conforme sustenta o autor (id., ibdem, grifo nosso).

Na visão de Gomes (2007: 116), isso "não significa a passagem de uma tradição discursiva a outra, não se trata de duas tradições discursivas, e sim uma mesma tradição discursiva passando por etapas de transformação". De acordo com a autora, o editorial manifestava-se, no século XIX, em um espaço variacional de textos de apresentação designados por: editorial de apresentação, artigo de apresentação, prospecto, introdução, e de textos opinativos designados por: artigo editorial, artigo comunicado, carta do redator, artigo de fundo. Embora recebam designações diferentes, parece que esses textos cumprem a mesma função social, conforme destaca a pesquisadora.

Partindo do que a perspectiva das TD propõe a respeito das mudanças que os gêneros podem sofrer, isto é, das transformações ocorridas a partir da ancoragem em gêneros já existentes ou de fenômenos externos que levam os gêneros a distanciarem-se de suas raízes, acredita-se ser possível traçar um paralelo entre os chamados artigos de fundo e as cartas de redator do século XIX, publicadas por O Farol Paulistano, e nelas, por sua vez, encontrar aspectos típicos dos textos combativos e panfletários. Do mesmo modo, ao analisar alguns elementos textuais em exemplares dos jornais Correio Paulistano e $O$ Estado de S. Paulo, entre eles as marcas de autoria institucional, entende-se ser possível estabelecer relações entre a carta do editor e o editorial, levando em conta que a opinião do editor corresponde e representa aquela proposta pelo grupo institucional, pelos chefes de redação, pelo conselho editorial (cf. Beltrão, 1980: 19).

Nesse sentido, a observação dos elementos linguísticos que permanecem e/ou se modificam ilustra a pertinência do conceito de TD para a análise da constituição dos gêneros discursivos, bem como propicia perceber como os gêneros podem apresentar um enraizamento em outros já existentes, processo no qual se verifica "um duplo movimento: repetição e mudança, isto é, uma tensão entre aspectos que permanecem, os quais possibilitam reconhecer o gênero, e aspectos variáveis, novos, determinados por novas conjunturas (...)" (Brandão, 2008: 33-4). 


\section{Editorial de jornal de bairro}

A imprensa de bairro brasileira ${ }^{12} \mathrm{e}$, dentro dela, especialmente a paulistana, vem crescendo e pluralizando-se de modo único desde a década de setenta. Seguindo a tendência de "desmassificação dos meios" (MEYER, 2004; SANT'ANNA, 2008) que acomete a contemporaneidade, relacionada a um deslocamento cada vez maior do consumo de informações do âmbito maciço e global para o regional e específico, as mídias especializadas e locais, voltadas para públicos mais homogêneos, tiveram seu campo de atuação e recepção aumentados, garantindo um espaço mais amplo no mercado simbólico.

A imprensa paulistana de bairro destaca-se no âmbito dos jornais locais. Com tiragens que superam a faixa dos 5 milhões de exemplares por mês, contando com cerca de 60 periódicos filiados à AJORB (Associação de Jornais e Revistas de Bairro de São Paulo) - o que exclui outros periódicos existentes, não vinculados à associação -, a imprensa de bairro da capital paulista consiste na imprensa regional mais ampla e plural do país e uma das mais diversificadas do mundo.

Segundo Peruzzo (2006), a mídia local foca tanto na temática regional não abordada pela grande imprensa, quanto em assuntos mais globais, analisados partir de uma perspectiva regional, de modo que o olhar local se torna justamente o nicho de mercado de tais veículos. Nesse sentido, trata-se de empresas de comunicação que visam ao lucro tanto quanto outros tipos de mídia, não podendo ser confundidas com a mídia comunitária, de gestão mais democrática e participativa, que envolve o cidadão em si na construção daquilo que será veiculado no periódico, não objetivando, em geral, o lucro.

Dornelles (2000: 106), por sua vez, destaca que o periódico local representa "uma grande série de atividades, valores e aspirações presentes na comunidade e que não são expressas na imprensa diária. Ele fornece um fluxo de notícias específicas para ajudar na adaptação às instituições e comodidades da vida urbana e interpretar, num contexto significativo e afetivo, os acontecimentos externos que são importantes para a comunidade alvo".

Tal caráter afetivo e regional caracterizam um modelo diferenciado de imprensa, que atualiza padrões e regularidades discursivas, genéricas e estilísticas

12 Pesquisa de Paulo Roberto Gonçalves Segundo, intitulada Tradições discursivas em editoriais da imprensa paulistana de bairro, sob orientação da Profa. Dra. Maria Lúcia da Cunha Victório de Oliveira Andrade. 
relativamente diferenciadas em relação à grande imprensa. Nesse sentido, é possível verificar, pela configuração das TD, de que maneira os textos produzidos pela imprensa de bairro repercutem modelos alternativos de produção textual, em menor ou maior grau.

A própria diversificação de títulos e a diferente identidade institucional assumida pelos diferentes periódicos colaboram com o processo de alternatividade, de modo que há jornais cujas produções textuais assemelhamse fortemente às da grande imprensa, enquanto outros se afastam intensamente dos modelos hegemônicos.

A análise dos editoriais produzidos por essa imprensa permite, tendo em vista o fato de esse gênero representar a voz institucional do periódico, depreender tanto aquilo que a organização considera relevante como alvo de opinião e comentário para sua comunidade leitora assim como a imagem que pretende construir de seu engajamento naquela região, como um agente intermediário entre o consumidor textual e os meios decisórios do poder político.

Nesse sentido, a partir de um corpus composto por 118 editoriais, coletados a partir de dois períodos históricos distintos -46 , pertencentes ao período que corresponde, grosso modo, à ditadura militar; 72 , concernentes ao século XXI -, foi possível depreender três grandes modelos identitários de jornal na imprensa de bairro paulistana, focando em suas prioridades temáticas ${ }^{13}$ :

1. Grupo A (imprensa local de abordagem global): jornais que priorizam a análise sociopolítica a partir do olhar avaliativo regional. Em geral, a temática sociopolítica predomina, com atualizações decrescentes em termos de temáticas regionais, de eventos significativos e datas comemorativas com significado político claro. Nesse sentido, minimizam a abordagem de temáticas cotidianas.

2. Grupo B (imprensa local de abordagem específica): periódicos que privilegiam a abordagem local, com análises e comentários avaliativos acerca tanto de eventos sociopolíticos quanto cotidianos relevantes na região durante dado período, sem ausentar-se, no entanto, de também analisar a conjuntura sociopolítica mais ampla.

3. Grupo C (imprensa local de abordagem plural): veículos de comunicação regional que apresentam uma abordagem mais plural da realidade, abar-

13 Deve-se ressalvar que tal categorização não pretende possuir caráter exaustivo e englobar, inequivocamente, todos os periódicos da imprensa local paulistana. 
cando temas cotidianos, sociopolíticos e regionais, e valendo-se da construção de uma maior aproximação entre leitor e periódico, exponencializando a tendência de desmassificação dos meios.

Tendo isso em vista, buscou-se analisar de que modo os editoriais eram estruturados pela imprensa de bairro, especialmente no que se refere à negociação intersubjetiva processada entre a produção e o consumo textual, uma vez que a relação de autoridade, credibilidade, intimidade e distanciamento, como variáveis relacionadas a poder e autoridade discursivos, apresentam-se de modo bastante idiossincrático nessa modalidade de imprensa.

Assim, denominou-se modo de negociação intersubjetiva (MNI) os subpotenciais semântico-discursivos que instauram padrões probabilísticos de recursos linguísticos correlacionados à metafunção interpessoal (HALLIDAY; MATHIESSEN, 2004), responsáveis pela filtração de potenciais escolhas do componente da avaliatividade, modalidade, envolvimento e exortatividade, que, atuando de forma compósita, compõem e atualizam TD ${ }^{14}$.

Nesse sentido, procura-se mostrar, nesse artigo, de que modo a perspectiva de TD permite depreender padrões de regularidades nos textos e também no seio dos próprios gêneros, procurando desvelar os agentes organizadores da dinamicidade acional do ponto de vista discursivo-textual. Destacam-se quatro grandes MNI no corpus em questão: o crítico e o exortativo - mais próximos aos modelos hegemônicos de editorial -, e o exaltativo e o informativo - situados em uma relação de alternatividade no que se refere ao modelo hegemônico.

Vejam-se alguns trechos de editoriais de cada um desses $\mathrm{MNI}^{15}$ :

(1)

\section{Octavio Frias de Oliveira, o eterno exemplo do empreendedor}

Há pessoas que nascem para mostrar ao mundo que todos os momentos da vida existem, para que levemos adiante projetos e ideais.

14 Deve-se ressaltar que uma abordagem linguística das regularidades que compõem uma TD requer uma abordagem funcionalista da linguagem e, dependendo dos objetivos do analista, uma aproximação com teorias discursivas e sociológicas. Neste artigo, a base funcionalista consiste na sistêmico-funcional (HALLIDAY; MATHIESSEN, 2004; MARTIN; WHITE, 2005).

15 Os textos foram transcritos de modo fiel às publicações originais. Nesse sentido, eventuais desvios em relação à norma culta são de responsabilidade do periódico. 
Encontrar pela frente um novo desafio lhes serve para despertar a mente em busca de soluções inovadoras.

Tais seres humanos são pioneiros devido a uma visão especial das possibilidades de um ou outro empreendimento. Para eles, os obstáculos são degraus que os fazem alcançar a realização de seus planos.

Tornam-se onipresentes pelo exemplo que dão ao se dedicarem ao trabalho, buscando a proximidade da perfeição. Não se preocupam em exercer atividades diferenciadas, pois é isto que os impulsiona e lhes dá, a cada dia, uma nova visão de vida.

Octavio Frias de Oliveira provou ser uma dessas pessoas, que se comprometeu em alcançar o sucesso, não só para seu próprio bem, mas também de todos que, de alguma forma, estivessem ligados a ele. [...]

Até a idade em que Octavio Frias de Oliveira faleceu, 94 anos, prova a sua tenacidade em relação à vida e suas realizações sempre servirão de exemplo, não só para empresários ou jornalistas, mas a todos os seres humanos que lutam para alcançar seus ideais, não importando quais sejam, nem a idade e nem quando irão se sentir motivados a buscá-los. Com sua lição de vida, aprendemos que o essencial é estar sempre em busca de novos horizontes, pois sempre há algo novo a ser alcançado. (SP Norte, 04 a 10 de maio de 2007 - no 257)

Note-se como a voz autoral inicia o texto tecendo uma série de avaliações positivas, inscritas e invocadas, acerca de um tipo específico de indivíduo, posteriormente identificado como o ator social Octavio Frias de Oliveira, falecido naquela época e editor da Folha de S. Paulo. Repare-se que há todo um conjunto de julgamentos que exaltam o ator social, numa postura laudatória da realidade. A construção da imagem do editor é exemplar, de modo que este é construído como um modelo a ser seguido pelos consumidores textuais. Trata-se de um exemplar da TD exaltativa, muito comum aos editoriais que constituem o corpus do século XX, no contexto da ditadura militar, mas também presente - em número reduzido - no corpus do XXI.

Nesse MNI, a voz autoral institui para si uma forma de autoridade bem idiossincrática, uma vez que se constrói como aquele que reconhece um modelo e, portanto, inferioriza-se em relação a ele, mas, por outro lado, iguala-se aos demais consumidores textuais no papel de potenciais discípulos, diferenciando-se apenas pelo seu papel divulgador. Por conseguinte, as inscrições afetivas - como motivados - tendem a ser compartilhadas com os leitores por formas de primeira do plural - aprendemos que -, mas o reconhecimento da autoridade tende a ser marcado de forma impessoal, ressaltando a exclusividade da divulgação. 
(2)

\section{Os intocáveis}

O "caso" Renan Calheiros não mais surpreende depois de uma série de situações parecidas que vemos continuamente estampadas nos dois últimos anos. Se não surpreende, causa desconforto para um povo assustado com a violência e desrespeitado pela corrupção.

Por esta impunidade enraizada na "Família" formada por alguns políticos, os culpados de hoje tornam-se as vítimas de amanhã.

As desculpas de sempre: É a imprensa que os persegue; são os terroristas opositores do governo, aqueles, da outra família, que criam armadilhas aos inocentes e incautos parlamentares, acusados injustamente, que sempre dizem ter provas de inocência; são os fatos, colocados de forma negativa, que são habilmente manipulados, mas, se usam do mesmo recurso, estão sendo estrategistas políticos, geralmente usando alguma causa social para vender sua proteção em defesa de seus eleitores. [...] (SP Norte, 29 de junho a 05 de julho de 2007 $\left.\mathrm{n}^{\mathrm{o}} 265\right)$

Note-se que, numa oposição diametral ao texto anterior, a voz autoral assume uma postura condenatória da realidade tematizada, de modo que são as avaliações negativas que se destacam na caracterização dos eventos e atores sociais. São especialmente os julgamentos de sanção social - ligados à ética e honestidade - e os afetos negativos que são atualizados como forma de convencer o consumidor textual de dado posicionamento autoral diante do tema, sempre de teor resistente.

Tais textos, vinculados ao MNI crítico, apresentam, em geral, uma alta densidade argumentativa, moderada atualização de recursos de envolvimento, como oralidade concepcional, por exemplo, além de mínima exortatividade, uma vez que é o convencimento o foco desta tradição.

Assim, o editorialista constrói para si uma autoridade baseada no conhecimento e no engajamento, uma vez que atua como um agente de denúncia acerca de dada realidade, divulgando-a para os consumidores textuais. Nesse sentido, como agente de denúncia, a voz autoral deve vincular-se a uma imagem de propriedade positiva, no sentido de que seus valores devem, em geral, identificar-se aos da comunidade leitora, a fim de que esta admita o editorialista como uma voz dotada de credibilidade. De fato, os textos críticos apresentam um baixo nível de polemicidade em relação aos valores pressupostamente construídos da comunidade leitora. 
(3)

Inaugurado em setembro de 2004, o Parque da Juventude ainda é uma das grandes novidades da região. Com $240 \mathrm{mil} \mathrm{m}{ }^{2}$, este parque público reúne quadras poliesportivas, playground, pista de Cooper, uma grande área verde e instalações destinadas a atividades de educação e cultura. A entrega de todo o complexo em etapas diferentes foi ampliando o leque de opções dentre esporte, lazer e cultura para a região. Mesmo assim, a maioria dos moradores da Zona Norte ainda não o conhece ou frequenta.

Esse fato foi comprovado por uma pesquisa recentemente realizada pela administração do parque, que pretende aumentar a frequência de 90 mil pessoas por mês para 150 mil até o próximo ano. Além da divulgação das atividades já realizadas, a administração aposta em novas parcerias e implementações para integrar o Parque da Juventude à população. Entre as principais ações, está prevista a construção de um novo estacionamento com 300 vagas, sendo esta uma das carências mais evidentes do local.

A frequência, ainda baixa, do Parque da Juventude pode estar ligada à recente história da Casa de Detenção, que durante décadas foi uma referência de fugas, rebeliões e violência com repercussão em todo o mundo. Para o morador da Zona Norte, é comum a lembrança da antiga Casa de Detenção ao passar pela Avenida Cruzeiro do Sul e sentir uma certa "surpresa" ao defrontar-se com os pavilhões agora totalmente transformados em espaços para educação e cultura.

Conhecer o Parque da Juventude ou participar das atividades gratuitas é uma das melhores opções da região neste período de férias. [...] (A Gazeta da Zona Norte, 7 de julho de 2007 - n 2266)

É possível observar que, diferente dos outros textos, a voz autoral assume uma postura analitica da realidade, descrevendo o objeto tematizado Parque da Juventude - por meio de apreciações, informando o leitor acerca da realidade do local e apresentando as prováveis causas para sua baixa frequência e os planos da administração para a melhoria do parque.

Não há julgamentos positivos ou negativos que construam um modelo ou um anti-modelo, não há condenação ou louvor da realidade. A voz autoral constrói-se como uma autoridade por conhecimento, demonstrando seu engajamento com a região e recomendando aos consumidores sociais a visitarem o parque, numa atitude exortativa. No entanto, não há clara vinculação afetiva, alta inscrição de recursos de envolvimento ou mesmo julgamentos para que se possa vincular tal texto a uma tradição exortativa. Trata-se apenas de uma exor- 
tação relacionada ao eixo da recomendação, não visando a uma mudança substancial do status quo. Nesse sentido, tem-se um texto de caráter informativo.

(4)

Ei-nos chegados novamente à realidade das coisas.

No domingo p. passado, em memorável jantar, ficaram definitivamente encerradas as lutas da Copa-74.

Dizer-se que o Brasil fez "papelão", é injusto. Quando alguém parte para uma guerra, onde defenderá os valores e as tradições de sua Pátria, ainda que com o coração sangrando, segue para vencer. Ninguém admite a derrota. [...]

Preparemo-nos para a Copa-78, quando em campos da Argentina, aqui mesmo na América do Sul, mostraremos os nossos valores e, quem sabe? poderemos trazer de lá o suspirado "caneco". A verdade é que a presença dos nossos atletas que nos representaram lá fora, nessa ultima maratona, deveremos mostrar-lhes o nosso respeito e o nosso carinho, pois eles também, queriam ser vitoriosos e tudo fizeram para conseguir uma vitoria que não quis sorrir para as nossas cores desta vez. Vamos em frente. A vitoria é dos fortes, é dos que lutam com tanto ardor e desprendimento que sabem, em ultima instancia, transformar em vitória até mesmo uma derrota. (Correio da Zona Sul, 12 de Julho de 1974)

Note-se que a voz autoral, no caso, constrói uma situação-problema, identificada com a derrota brasileira na Copa de 74. A tal situação, atrela soluções e comandos para que essa possa ser superada. O último parágrafo apresenta os comandos propriamente ditos, associados à preparação para a Copa seguinte, a mostrar carinho e respeito aos jogadores, a ir em frente, buscando persuadir a comunidade leitora a agir de modo receptivo em relação aos jogadores, utilizando de argumentos que reconhecem o esforço da equipe e minimizam sua culpa diante do ocorrido, utilizando inclusive de inscrições afetivas e primeira pessoal do plural inclusiva para vincular-se ao leitor.

A necessidade de vinculação decorre do fato de a voz autoral precisar construir um tipo de autoridade diferenciada para conseguir exortar e persuadir o leitor a agir de determinada maneira. A construção da intimidade e o envolvimento, relacionados à solidariedade, constituem premissas para a exortação, de modo que os recursos de envolvimento consistem em formas estratégicas para obtenção de tal adesão. Nesse sentido, tem-se uma autoridade de vivência e de proximidade, comum a muitos textos exortativos, que se basei- 
am no estreitamento da relação interpessoal como forma de embasar os comandos.

É possível observar, portanto, que a concepção de TD, aliada a uma teoria funcionalista, permite depreender os diferentes padrões constitutivos dos gêneros, atentando para sua dinamicidade interna e para os diversos modos de instauração da negociação intersubjetiva nos textos.

\section{Cartas do leitor}

As cartas do leitor estão relacionadas a assuntos vividos pela sociedade da época e noticiados nos jornais ou a aspectos pessoais. Daí a motivação para escrever no jornal, tendo a possibilidade de o leitor publicar sua crítica, opinião ou pedido pessoal.

O corpus selecionado para este estudo ${ }^{16}$ é constituído de cartas publicadas entre os anos de 1828 e 1893, nos seguintes jornais paulistas: O Farol Paulistano, Diário de S. Paulo, A Provincia de S. Paulo, Correio Paulistano ${ }^{17}$. O contexto de situação em que as cartas se efetivam está revelado no próprio texto. Tal revelação não se dá de uma forma mecânica, mas por meio de um relacionamento sistemático entre o meio social, de um lado e a organização funcional da língua, de outro.

A carta do leitor é um texto que circula no contexto jornalístico em seção fixa de jornais e revistas, denominada comumente de cartas, cartas à redação, carta do leitor, painel do leitor, destinada à correspondência dos leitores. É utilizada em situação de ausência de contato imediato entre remetente e destinatário, que não se conhecem (o leitor e a equipe editorial do jornal ou da revista) visando a atender vários propósitos comunicativos: opinar, agradecer, reclamar, solicitar, elogiar, criticar, entre outros. É uma TD de domínio público, de caráter aberto, com o objetivo de divulgar seu conteúdo e possibilitando a sua leitura ao público em geral.

16 Pesquisa de Maria Lúcia da Cunha Victório de Oliveira Andrade, intitulada Tradições discursivas e cartas do leitor publicadas em jornais paulistas do século XIX ao início do século XX, parte dos trabalhos desenvolvidos dentro do PHPP.

17 Material organizado por Ataliba Castilho, Marcelo Modolo, Marilza de Oliveira e Verena Kewitz, e publicado em: BARBOSA, A. e LOPES, C. (orgs). Críticas, Queixumes e Bajulações na Imprensa Brasileira do Século XIX. Cartas de Leitores. UFRJ/FAPERJ, Rio de Janeiro: 2006 
$\mathrm{Na}$ atualidade, as cartas do leitor são divulgadas em jornais e revistas de grande circulação e tratam de notícias ou reportagens de temas de interesse nacional, publicadas nesses veículos de comunicação, ou de solicitações feitas pelos leitores, pois é de fácil acesso, revela um contato, por parte deles, com os fatos importantes e recentes da sociedade e está escrito em registro formal ou semi-formal do Português.

Sabemos que nem toda carta do leitor é publicada. Segundo Melo (1999: 28-29), há sempre uma triagem para a seleção das cartas a serem efetivamente publicadas e entre aquelas que são selecionadas para publicação pode haver ainda uma edição, como ocorre normalmente nos Jornais Folha de S. Paulo, $O$ Estado de S. Paulo, Jornal da Tarde ou nas Revistas Veja ou Época, por exemplo. Por razões de espaço da seção ou por direcionamento argumentativo, as cartas podem ser resumidas, parafraseadas ou mesmo ter informações eliminadas. O que configura, segundo Bezerra (2002, p. 211), "uma carta com co-autoria: o leitor, de quem partiu o texto original, e o jornalista, que o reformulou". Entretanto, nos jornais do final do século XIX não é bem isso o que se vê. Na verdade, nos jornais selecionados as cartas são apresentadas integralmente e versam sobre os mais variados e distintos assuntos: pedidos, reclamações, comentários, busca de contato com parentes ou amigos, entre outros.

Nas cartas selecionadas, encontramos um exemplo significativo em que o escrevente faz uso da estrutura narrativa para contar um diálogo que ouvira, quando estava descansando na ponte do ferrão, entre um senhor português e um estudante brasileiro. Esta carta foi publicada no Farol Paulistano, em 15 de março de 1828. Vejamos um pequeno trecho:

\footnotetext{
"Senhor Redactor - Depois de cessar um pouco essa abundante chuva, que desde o anno passado tem caído todos os dias sem interrupção, quis ver o estado da varzea do Carmo, e se com effeito tinhase conseguido o fim d'esgotá-la, dirigi-me até a chamada ponte do ferrão, que foi entulhada e vi o pêso das aguas, que não respeita grandes barreiras (...)De volta sentei-mea descançar na ponte fraca e aí estavão talvez ao mesmo fim dois sugeitos, um dos quaes era um Portuguez velho, e Brasileiro novo, (...) Logo que cheguei encetavão elles uma conversação,e por me parecer interessante apenas voltei a casa tracteri d'escrevê-la para me não esquecer, e suppondo que possa alguem julgá-la tambem interessante lh'a envio para que se digne publicar no seu Farol."
} 
Já a carta selecionada no exemplo (6) - publicada no Correio Paulistano, em 22 de julho de 1893 - é construída com base na descrição de um indivíduo. Observemos:

\section{(6) Rio Verde}

Ha mezes que appareceo nesta cidade um individuo alto, corcunda, espadaúdo, meio careca; ao longe parece com corvo mestre e outros disem que com o abestruz e eu me inclino para quaesquer das duas aves. Disem chamar-se "Cruz", este antigo pa- tibole de malfeitores, emfim pelo nome não se perca.

Disem tambem ser amphibio, porem não parece pela pelle; que é orgam hoje e outros que é Realejo por ter manivella. Ja ouvi tratal-o de ganso e doutor Scismado, mas não sei se attende por esses nomes. $\mathrm{O}$ que sei é que ja foi juiz, cujas bravatas existem em cartorio onde exerceo esse cargo, despachando em um inquerito onde disem, era indiciado e hoje é representante da so ciedade.

Sei mais que scisma soffrer dos pulmões e nem as pedras o convencem do contrario. No jury tem voz aflautada e as vezes parece guincho de vehiculo de duas rodas, e me affirmam mesmo que toca flauta e flautim. Pretende, havendo mudança de situação ser nomeado juiz de direito de uma Comarca visinha. O seu ar é de bôbo e por isso muito esquivo. Advinhem: quem é o biographado ?

Rio Verde, 15 de Julho de 1893.

JOÃO CALDAS.

Os enunciadores das cartas selecionadas em nosso corpus são pessoas que vivem na cidade de São Paulo e procuram, através do jornal, atingir propósitos bem específicos e variados. Dentre as cartas levantadas, destacam-se: pedido; reclamação; desabafo; comentário sobre matéria publicada, comentário ou crítica a políticos, sobre as escolas públicas, as condições das estradas, iluminação pública, limpeza urbana; biografia; confissão.

Em algumas correspondências o propósito é explicitado pelo enunciador, aparecendo em posição de destaque logo no início do texto. Com freqüência, o objetivo da carta não é indicado tão claramente, devendo ser inferido. Vejam-se alguns exemplos:

\section{(7) Escola do Arujá}

Passando pela freguezia do Arujá, tive occasião de ver ali funccionando a escola publica regida pelo senhor Caetano Nunes de 
Siqueira, ha pouco para ali removido. Tem o $\mid$ distincto professor matriculados sessenta e tantos alumnos em lugar tão insignificante, que muito têm aproveitado, e de entre os quaes alguns ja estão bem adiantados, comquanto para a mesma escola entrassem sem conhecimento algum das materias que ali se ensinão. (...) (Diario de São Paulo, 23 de maio de 1874)

\section{(8) A Companhia de Navegação Paulista}

Senhores Redactores. - Li por duas vezes, no jornal de vv.ss., reclamações sobre a irregularidade dos vapores desta companhia e da desconsideração com que se tratava os Paulistas, deixando de os avisar das transferencias por meio de annuncios, etc. (...) (A Provincia de S. Paulo, 12 de março de 1875)

Na carta, seqüências narrativas, descritivas, argumentativas convivem harmoniosamente, por isso, muitas vezes, é difícil delimitar as porções de cada tipo textual, que se sucedem numa progressão/transição quase imperceptível. Cabe lembrar que o estudo dessa mescla dos tipos de estruturas textuais não pode ser desvinculado do estudo da organização tópica. (tema de cada carta)

A carta de leitor é sem dúvida uma TD que foi se alterando conforme as transformações tecnológicas que o jornalismo e a sociedade foram recebendo. Trata-se de uma correspondência em que diversas estruturas podem estar na base de sua composição. Seu propósito, porém, é basicamente o mesmo: ser um meio ou canal de interação entre os leitores e o jornal em que é publicada com o propósito de manter um diálogo relativo às práticas sociais de seu tempo.

\section{Noticiário}

Nesta seção, são apresentados aspectos de uma pesquisa de pós-doutorado $^{18}$ que assume, como objetivo, investigar, analisar e descrever as estruturas responsáveis pelo estabelecimento das relações interpessoais e as intersecções destas com a persuasão no noticiário dos jornais paulistas acerca

18 Pesquisa de pós-doutorado de Fabio Fernando Lima, intitulada Persuasão e constituição de consensos na mídia impressa paulista: o noticiário sobre as eleições (séc. XIX, XX e XXI), processo FAPESP n ${ }^{\circ}$ 09/54845-6. 
das eleições compreendidos entre os séculos XIX, XX e XXI, observando a manifestação de ideologias e a busca pelo estabelecimento de determinados consensos. Paralelamente, levando em consideração a diacronia do gênero textual sob análise, busca-se descrever sua evolução, regularidades e transformações, apresentando, assim, as TD do noticiário nos jornais paulistas.

De acordo com os objetivos que norteiam este artigo em particular, o segundo ponto destacado no parágrafo anterior, que se refere à descrição das TD do noticiário nos jornais paulistas, ganhará primazia sobre o primeiro.

No que concerne ao material selecionado para esta pesquisa, propriamente o noticiário sobre as eleições, cumpre dizer, em primeiro lugar, que emerge de uma maneira bastante difusa, permeando outros gêneros discursivos do jornalismo impresso. Paralelamente, observa-se que, desde as eleições gerais de 1889 para a Câmara dos Deputados, a última realizada sob o império, passando pela Primeira República (1889 a 1930), os jornais adotam uma determinada posição partidária na arena política, e a argumentação estabelecida nesses materiais visa claramente a obter a adesão do leitor a este mesmo ponto de vista.

Na realidade, tais publicações ecoam os anseios da aristocracia de São Paulo da época, a qual passa a se expandir para o campo empresarial e político-administrativo. Como pano de fundo, a Revolução Industrial e a necessidade de se criar novos mercados consumidores. A dificuldade do Governo Imperial em satisfazer esta e outras demandas, mesmo após a abolição da escravatura, abre espaço para um consenso, na aristocracia, acerca da necessidade de substituição do governo monárquico por um governo Republicano (cf. Veloso e Madeira, 2000).

O trecho destacado a seguir, retirado do jornal A Província de S Paulo, dia 2 de agosto de 1889, é ilustrativo da maneira como as eleições eram tratadas nos jornais paulistas ao longo deste período:

\section{(9) Monarchicos e Republicanos}

As inconsequencias dos monarchicos, a falta de fé nas instituições e o apoio condicional que muitos lhes prestam mais por conveniencias pessoaes que por julgal-as necessarias e uteis, levaram o paiz a este estado de incerteza, de perturbação e de anarchia.

Tomemos para exemplo a provincia de S. Paulo onde os tres partidos se batem com mais moralidade e cordura que em algumas outras. Liberaes, conservadores e republicanos disputam cargos da represen- 
tação nacional e apresentam candidatos pelos noves districtos. O exemplo aqui é expressivo. Os liberaes, tolos governistas, dividem-se entretanto em federalistas com ou sem corôa, guardadas as reservas mentaes segundo a educação jesuitica, e federalistas sem a verdadeira significação do termo technologia política, aptos para apoiar todas as nuanças do liberalismo.Representam o primeiro os candidatos do $1^{\circ}$ e $6^{\circ}$ districtos e o segundo, todos os dos outros districtos.

Mas aquelles mesmos não disseram ainda ás claras, com a precisa lealdade, o que pretendem, uma vez eleitos. O do primeiro embrulhase em certas conveniencias partidarias e por ahi vai atravessando como um bom governista (...)

Só as candidaturas republicanas trazem a luz a esse cahos em que se debatem os monarchicos.

Basta terem por programa a Republica para exprimir uma nova ordem de cousas, um systema de federação, o unico possível, conforme o pensar de politicos eminentes como os srs. Ferreira Vianna, Andrade Figueira, Mendes de Almeida e outros.

A luta só póde ser collocada neste terreno: ou federação com a Republica ou descentralização com a monarchia: de um lado republicanos e do outro monarchistas.

Deixa, porem, de ter razão de ser a diversidade de candidatos e portanto a legitimidade da candidatura do sustentador da monstruosidade que é a ruína da monarchia e de um erro que o illustre Sr. Presidente do conselho está obrigado a não deixar de ter effeito sob a sua responsabilidade de real monarchista. Como republicano, sim, s. exc. deve acceitar a federação porque só assim traduzirá a vontade soberana da nação consultada livremente. (APSP, 02/08/1889)

As marcas do(s) enunciador(es) claramente delineadas, aliadas à expressão de um determinado posicionamento a respeito do tema, confere ao texto uma natureza mais próxima dos editoriais contemporâneos que do próprio noticiário. No entanto, ao longo de todo o processo eleitoral para as eleições gerais de 31 de agosto de 1889, é assim que A Província de S,Paulo noticia os eventos relacionados às eleições, imiscuindo visivelmente, em todas as edições, a narrativa dos fatos noticiados e toda a sorte de argumentos ${ }^{19}$.

No trecho em destaque, observamos uma primazia dos argumentos que Perelman e Olbrechts-Tyteca (1996) denominam "pragmáticos", especialmente do tipo causa e efeito (por exemplo, as inconsequencias dos monarchicos

19 No que se refere aos tipos de argumentos tomamos por pressuposto, nesta pesquisa, o inventário das "técnicas argumentativas" apresentado por Perelman e Olbrechts-Tyteca (1996). 
(...) levaram o paiz a este estado de incertęa), imiscuídos à fundamentação do real pelo recurso ao caso particular (tomemos para exemplo A Provincia de S. Paulo), dentre outros.

A esse tipo de texto, acrescente-se, no que se refere à cobertura das eleições, a publicação diária do Boletim Republicano, em que ora são publicadas cartas dos líderes do Partido Republicano Paulista, ora apresentada a lista de candidatos do partido para as eleições, ou ainda noticiadas adesões de políticos ao mesmo partido. Neste último caso, é constante a descrição enaltecedora dos feitos destes homens ao longo de sua vida pública.

Raramente, observam-se breves relatos mais característicos do próprio noticiário, os quais, muitas vezes, fazem uso do argumento de autoridade, como o que segue:

\section{(10) As eleições em Botucatu}

Pessoa criterioza, chegada de Botucatu, informa-nos que ha naquella localidade uma força destacada com o fim de impedir que as eleições de 31 corram livremente.

Será bom o governo informar-se a respeito. (APSP, 22/08/1889)

Ao longo da Primeira República, é possível perceber um direcionamento maior do noticiário sobre as eleições para o eixo narrativo, além de algumas alterações no campo de sua estruturação, especialmente no que concerne à subdivisão em seções pré-determinadas, embora a mesma ligação com os partidos políticos possa ser observada. Assim, no Correio Paulistano, além da publicação diária da seção "Eleições Federaes", em que é apresentada a lista de candidatos do Partido Republicano, acrescida da descrição dos "valores" de cada um deles, são encontradas seções separadas em que se observam narrativas de fatos, ora dedicadas a enaltecer a campanha e apresentar argumentos favoráveis ao candidato do Partido Republicano, Júlio Prestes, ora apresentando fatos e argumentos desfavoráveis ao candidato do Partido Democrático, Getúlio Vargas. No caso de O Estado de S. Paulo, também observamos a predominância do gênero narrativo, mas com o viés político contrário. Os exemplos seguintes são ilustrativos desse período: 


\section{(11) A excursão eleitoral pelo $3^{\circ}$ Districto}

Apotheose de São Jose do Rio Pardo aos candidatos Nacionaes

Foram imponentes manifestações que o povo riopardense prestou aos eminentes candidatos Julio Prestes e Vital Soares - Milhares de Pessoas aguardavam, na estação, o dr. Fabio Barreto e sua comitiva - o grande enthusiasmo popular - No comicio, realisado no "Pavilhão XV de Novembro", a multidão applaude os nomes dos dois brasileiros indicados aos postos de Presidente e Vice-Presidente da Republica (...) $(\mathrm{CP}, 31 / 01 / 1930)$

\section{(12) Em S. Paulo}

A Campanha do Partido Democrático

Concorrido comicio em Santa Barbara

Santa Barbara, 17 - Realisou-se domingo, ás 18 horas e meia, na Praça Rio Branco, desta cidade, um concorrido comício promovido pelo Partido Democrático.

Falaram durante essa manifesação, sendo muito appláudios pela assistencia, os srs. drs. Moacir do Amaral Santos, Aldrovandro Fleury e Paulo Caracedo, fazendo a propaganda dos canditatos liberaes á Presidencia e Vice-Presidencia da Republica. (...)

Reinou, durante o comicio, completa ordem. (OESP, 19/02/1930)

Conforme aponta Bahia (1990, p. 138), a partir da década de cinqüenta os jornais sofrem importantes reformas que abrangem, dentre outros aspectos, formato, composição e conteúdo. Há, de acordo com o autor, transformações técnicas que visam a tirar o foco do ponto de vista político. Mas foi, sobretudo, com o fim da ditadura militar e a redemocratização, em 1985, que os jornais paulistas de maior circulação passaram a assumir, como premissas para suas linhas editorias, a busca por um “jornalismo crítico", "apartidário” e "pluralista" 20 . No que concerne aos gêneros discursivos, a subdivisão hoje conhecida em seções claramente delineadas, com as marcas características de cada uma delas (editoriais, cartas dos leitores, artigos de opinião, noticiário, etc.) vão tomando forma.

No entanto, apesar do discurso consensual, presente nas mídias modernas, a propósito da necessidade de uma cobertura imparcial dos fatos, po-

20 Cf. Folha de S. Paulo. Projeto Editorial 1985-1986. Novos rumos: Depois da redemocratização. Julho de 1985. 
sição que atribui ao gênero "notícia" o relato imparcial de acontecimentos recentes, marcado por uma "função comunicativa" de "informar" com neutralidade e de maneira objetiva, partimos do princípio de que essa tarefa esbarra nas próprias condições de produção do texto. Isso porque, de acordo com a vertente teórica que fundamenta esta pesquisa, propriamente a Análise Crítica do Discurso, os sentidos não são dados a priori, mas construídos por indivíduos ou grupos que, enquanto sujeitos sócio-históricos, elaboram e interagem com textos produzidos a partir de contingências atreladas a estruturas e processos sociais, os quais tomam parte.

Nessa perspectiva, o jornalista escreve tanto como representante profissional de determinada instituição de comunicação quanto membro de um determinado grupo social, postura esta que, conforme assinala Van Dijk (2008), molda suas cognições sociais, suas ideologias e, por conseguinte, o processamento de informações acerca do fato a ser noticiado.

Dessa maneira, a persuasão e o controle são exercidos, no noticiário contemporâneo, não mais a partir de discursos que possuem funções pragmáticas diretivas, mas pelo controle do contexto, aqui entendido, em consonância com Van Dijk (2008), como algo constituído por categorias como a definição global da situação, seu espaço e tempo, as ações em curso (incluindo o discurso e seus gêneros), os participantes em papéis comunicativos, sociais ou institucionais variados, bem como suas representações mentais: objetivos, conhecimentos, opiniões, atitudes e ideologias. Controlar o contexto implica controlar uma ou mais dessas categorias, determinando, por exemplo, o estatuto da situação comunicativa, decidindo sobre o tempo e o lugar do acontecimento comunicativo, quais participantes podem/devem estar presentes nele, em que papéis, quais conhecimentos ou opiniões deverão ter ou não ter, e quais ações sociais podem ou não se cumprir por meio do discurso do discurso.

De forma análoga, o controle dos tópicos no noticiário, aquilo que poderá ou não ser dito, e sua subdivisão no interior do jornal, bem como as seleções operadas no nível lexical, apresentam-se como formas extremamente eficazes de controle ideológico.

Por fim, as operações de controle no nível de especificidade e grau de completude do texto também são apontadas pelo autor como muito relevantes. De acordo com o seu ponto de vista, a seqüência de eventos pode produzir diferentes graus de generalidade, alguns muito detalhados e claramente focalizados, outros vagos, difusos. Assim, os fatos que valorizam as ações dos 
grupos dominantes tendem a ser descritos de modo detalhado, enquanto os fatos incômodos não.

\section{Anúncios de emprego}

Nesta seção, tratamos do estudo sobre o gênero discursivo anúncio de emprego $^{21}$ no jornal O Correio Paulistano, a partir de 1854 (início de circulação) até 1900. Estudamos o processo de transformação desse gênero, fazendo uma pesquisa qualitativa e quantitativa de todos os exemplares desse período. Assim como o jornal, os anúncios retratam as condições econômicas, sociais e históricas de cada época, devido ao seu caráter documental "de modo que constituem a melhor matéria ainda virgem para o estudo e a interpretação de certos aspectos do século XIX" (Freyre, 1980: 58). Por essa razão, incluímos os aspectos ideológicos e sociais manifestados nos textos em análise.

No que tange aos estudos diacrônicos, utilizamos o arcabouço teórico das TD que permitem analisar, dentre outros aspectos, quais as TD que compõem os anúncios de emprego, quais as mudanças linguisticas mais significativas no decorrer do tempo e quais as possíveis causas para essas mudanças.

Em relação aos aspectos ideológicos históricos e sociais, fazemos uso dentre os diversos enfoques e metodologias de análise da ACD - do modelo tri-dimensional de Fairclough (2008:73) que propõe investigar a língua como prática social considerando o discurso como qualquer evento discursivo, entendido, simultaneamente, como um texto, uma prática discursiva e uma prática social.

Os anúncios (anúncios publicitários ou avisos) surgiram como uma medida eficaz para sanar os problemas financeiros dos jornais (Oliveira, 1978: 87). Inicialmente, não eram separados em classificados, vendia-se de tudo em um único espaço: escravos, cães, cavalos, mosaicos, produtos de padarias, entre outros. Anunciavam-se não só produtos, bens e serviços para a comunidade, como também logros, pedidos de empréstimos, perdas de objetos, pedidos de endereço, e até cobranças pessoais.

21 Pesquisa de doutorado de Kelly Cristina de Oliveira (2012), intitulada, provisoriamente, Tradições Discursivas: constituição e mudança do gênero anúncio de emprego no jornal Correio Paulistano - do século XIX ao início do século XX, sob a orientação da profa. Dra. Maria Lúcia da Cunha Victório de Oliveira Andrade. 
O gênero discursivo anúncio de emprego desenvolveu-se por causa da principal mudança social econômica ocorrida no Brasil: pessoas alforriadas e/ou livres substituindo escravos. Essa mudança foi resultado de vários acontecimentos históricos, dentre eles, Holanda (1985:162) destaca: Lei Feijó de 1831, que proibia a comercialização de afrodescendentes vindos da África; Lei Slave Trade Supression Act ou Lei Eusébio de Queiroz criada em 1845 e aprovada em 1850, que proibia o comércio de escravos entre a África e a América; Lei Rio Branco ou Ventre Livre lavrada em 1871, que garantia liberdade aos filhos de escravas nascidos no Brasi122 ; Lei Saraiva-Cotegipe ou Lei dos Sexagenários de 1884, que libertou idosos com mais de 60 anos, e finalmente em 1888 a Lei Áurea, que declarava extinta a escravidão.

Aspectos do cotidiano e da vida social dessa época podem ser acompanhados nas escolhas lexicais feitas, pois estão diretamente associadas às atitudes, às ideologias e às crenças dos interactantes (Fairclough, 2008: 106). Verbos como "alugam-se" e "vendem-se", por exemplo, passam a se referir gradativamente a objetos e não mais a pessoas. Também observamos a substituição gradual da expressão "não se duvida pagar bem" unido à expressão "exige-se perfeição" que aparecia com mais freqüência em anúncios para vagas femininas - denotando dominação e ausência de barganha por parte do futuro empregado - por "paga-se bem", expressão mais atrativa para o futuro empregado.

Com o tempo, as TD anúncio de emprego adquirem signo próprio, evidenciando o que Kabatek (2004a: 5) diz acerca da relação de um texto com o anterior: a partir de uma relação temporal, novas TD são criadas. O sujeito constrói o texto a partir de modelos já existentes na sociedade. E conforme suas práticas sociais evoluem, transformam-se os traços de mudança e de permanência desse gênero. $\mathrm{O}$ anunciante - que antes se servia de um mesmo anúncio para divulgar vagas de emprego e locação de imóvel ou venda de produtos ou serviços - passa a diferenciar as ofertas de produtos das de trabalho.

Os primeiros anúncios de emprego eram separados por janelas, ou seja, cada um ficava isolado por linhas laterais, superiores, inferiores, como se fosse um quadro. Não havia ainda a ideia de Classificados, o jornal era separado em três colunas.

22 Ressaltamos o fato de que ainda permaneciam escravos os nascidos antes dessa data até a extinção total da escravidão. 
Em 1854, verificamos que alguns foram publicados com a inicial de "P" para precisa-se. No ano seguinte, há algumas publicações de vagas contendo títulos em caixa alta.

Não nos parece que havia alguma intervenção do redator, a fim dar um acabamento padronizado e organizar os anúncios, como acontece nos dias atuais. Dessa forma, eram produzidos por sujeitos advindos de realidades econômicas e/ou sociais diversas que traziam seus modos particulares de dizer e, assim, determinavam as condições de produção textual. Eram de responsabilidade dos anunciantes o conteúdo e a forma de anunciar, isso fazia com que esse gênero tivesse marcas de pessoalidade.

Observa-se essa ausência de padrão, principalmente, nas chamadas. Os leitores tinham de ler toda a coluna de anúncios, pois os de emprego poderiam aparecer iniciados por: Aos senhores emigrantes, Com urgência, Atenção, Camaradas, convite ou uma locução adverbial de lugar. Convergiam ainda as TD de oferta de emprego com as de convites e de avisos.

Observamos que a partir de 1867 houve mudanças significativas na composição do jornal e na forma de anunciar as vagas para emprego. Há mais vagas escritas em caixa alta, agora com o texto centralizado, facilitando, assim, a sua localização. Também há mudanças nas dimensões do jornal, que passam a ter 4 colunas em cada página.

Embora houvesse variações quanto à composição interna do gênero, percebemos certa regularidade e repetição de alguns elementos que o constituíram: alguém anuncia, pessoa ou indústria; descrição da vaga; requisitos, não obrigatórios, mas contidos na maioria dos anúncios; e procedimento, onde ir e como fazer, caso esteja interessado.

Alguns anúncios continham mais palavras, outros menos, mas a presença desses 4 elementos cumpriu satisfatoriamente a função do gênero: ser uma mediação que conecta indivíduos, grupos, ocupações e organizações. Esse "esqueleto", responsável pela formação do gênero anúncio de emprego, prevalece até os dias atuais.

Em relação ao conteúdo, a análise do corpus evidenciou as principais mudanças social, econômica, histórica e cultural na sociedade paulista, dentre elas: pessoas livres substituindo os escravos; a presença de amas de leite brancas, em detrimento das negras; a presença do trabalho infantil; a entrada de imigrantes para o mercado de trabalho; as profissões mais significativas para o período, bem como suas representações na sociedade; as profissões exercidas 
exclusivamente por mulheres, por homens e por ambos; o progresso e o desenvolvimento urbano da Província de São Paulo com os anúncios de trabalhadores para a implementação de ruas, praças, luminárias, números de casas, estradas e ferrovias.

\section{Considerações Finais}

Apresentar uma visão geral do que estamos desenvolvendo em relação às tradições discursivas no interior do PHPP foi nosso intuito neste artigo. Esperamos ter conseguido levar o leitor a vislumbrar o que é o projeto Tradições Discursivas: constituição e mudança dos gêneros numa perspectiva diacrônica, bem como o conjunto de reflexões que foram aqui discutidas a respeito de cada gênero jornalístico da imprensa paulista selecionado para esta abordagem.

\section{Referências bibliográficas}

BAHIA, Juarez (1990). Jornal, história e técnica: história da imprensa brasileira. 4.ed. revista e aumentada. São Paulo: Ática, v.1.

BAHIA, Juarez (2009). Jornal, história e técnica: as técnicas do jornalismo. 5.ed. Rio de Janeiro: Mauad X, v.2.

BAZERMAN, Charles (2006). Cartas e a base social de gêneros diferenciados. In: DIONISIO, Angela P.; HOFFNAGEL, Judith C. (Orgs.). Gêneros textuais, tipificação e interação/Charles Bažerman. Tradução e adaptação de Judith C. Hoffnagel. 2.ed. São Paulo: Cortez, p.83-100.

BELTRÃO, Luiz. (1980). Jornalismo opinativo. Porto Alegre: Sulina.

BEZERRA, Maria Auxiliadora (2002) Por que cartas do leitor na sala de aula. In: A P. Dionísio, A R Machado e M. A Bezerra. Gêneros textuais e ensino. Rio de Janeiro: Lucerna.

BIBER, Douglas (1988). Variation across speech and writing. Cambridge: Cambridge University Press.

BORDIEU, Pierre. (1991). Outline of a theory of pratic Cambridge: Cambridge University. BOUVET, Nora Esperanza (2006). La escritura epistolar. Buenos Aires: EUDEBA.

BRANDÃO, Helena H. N. (2008). Discurso, gênero e cenografia enunciativa. In: MICHELETTI, Guaraciaba (org.) Enunciação e gêneros discursivos. São Paulo: Cortez.

BRANDÃO, Helena H. N.; ANDRADE, Maria Lúcia C.V.O.; AQUINO, Zilda G. O. de (2009). Cartas da administração privada e cartas particulares: estudo da organização discursiva. In: AGUILERA, Vanderci (org.) Para a História do Português Brasileiro - vozes, veredas, voragens. Tomo II, v.VII. Londrina: EDUEL, p.699-737.

CURTIUS, Ernst Robert (1955). Literatura Europea y Edad Media Latina. México: Fondo de Cultura Económica.

DISCINI, Norma (2004). O sujeito no jornal. In: Gragoatá. Niterói: EDUFF, $1^{\circ}$ semestre de 2004. no 16, p. 209-227. 
DORNELLES, Beatriz (2000). Imprensa comunitária: jornais de bairro de Porto Alegre. In: HAUSSEN, Doris Fagundes (org.) Mídia, imagem e cultura. Porto Alegre: EDIPUCRS, pp. 103126.

FAIRCLOUGH, Norman (2008). Discourse and Social Change. Cambridge: Polity Press.

FREYRE, Gilberto. (1980) Casa-Grande Senzala. Rio de Janeiro: Editora Record.

GOMES, Valéria Severina (2005). História do editorial jornalístico em Pernambuco: o que mudou e o que permaneceu no curso desta tradição discursiva? In: PESSOA, Marlos de Barros (org.). Lingua, textos e história: Manuscritos e impressos na história do português brasileiro. Recife: Programa de Pós-Graduação da UFPE, p. 87-107.

GOMES, Valéria Severina (2007). Traços de mudanças e de permanência em editoriais de jornais pernambucanos: da forma ao sentido. Tese (Doutorado em Linguística). Recife: Universidade Federal de Pernambuco.

HALLIDAY, M. A. K. (2004) Introduction to Functional Grammar. $3^{a}$ ed. London: Hodder Arnold. HOLANDA, Sérgio Buarque (1985). O Brasil monárquico. História Geral da Civilização Brasileira. 4 ed. Tomo II, Quinto Volume. São Paulo: Difel.

ISIDORO DE SEVILLA (1982). Etymologiarum (Etimologias). Edição bilíngue (latim-espanhol), tradução e notas de José Oroz Reta. Madrid: Biblioteca de Autores Cristianos, 2 volumes.

JOLLES, André (1976). Formas simples. Tradução de Álvaro de Cabral. São Paulo: Cultrix.

KABATEK, Johannes (2001). Cómo investigar las tradiciones discursivas medievales? El ejemplo de los textos jurídicos castellanos. In: Daniel Jacob/ Johannes Kabatek (eds.) Lengua medieval y tradiciones discursivas en la Peninsula Ibérica. Frankfurt am Main:

KABATEK, Johannes (2003). Tradiciones discursivas y cambio linguístico. Seminario de historia de la lengua española El cambio linguístico en la historia española: nuevas perspectivas. Soria, de 7 a 11 de Julio de 2003.

KABATEK, Johannes (2004). Sobre a historicidade de textos. Trad. José da Silva Simões. Linha d'água, 17. São Paulo: USP/APLL.

KABATEK, Johannes. (2004a). Algunas reflexiones sobre las tradiciones discursivas. Disponível em : http:/ / www.uni-tuebingen.de/kabatek/discurso/reflex.pdf. Acesso em: 10 jan 2010

KABATEK, Johannes (2006). Tradições discursivas e mudança linguística. In: LOBO, Tânia; RIBEIRO, Ilza; CARNEIRO, Zenaide e ALMEIDA, Norma (orgs.). Para a Historia do Português Brasileiro VI - Novos dados, novas análises, Salvador: EDUFBA, Tomo II, 505-527.

KOCH, Peter (1997). Diskurstraditionen: zu ihrem sprachtheoretischen Status und ihrer Dynamik. In: FRANK, Barbara; HAYE, Thomas; TOPHINKE, Doris (eds.). Gattungen mittelalterlicher Schriftlichkeit. Tubingen: Narr 1997 (ScriptOralia, 99), 43-79. (Trad.: Alessandra Castilho Ferreira da Costa)

MARCUSCHI, Luiz Antônio (2002). Gêneros textuais: definição e funcionalidade. In: DIONÍSIO, A. P.; MACHADO, A. R.; BEZERRRA, M. A. (orgs.). Gêneros textuais \& ensino. Rio de Janeiro: Lucerna, p.19-36.

MARTIN, J. R. \& WHITE, R. R. R. (2005) The language of evaluation: appraisal in English. New York/Hampshire: Palgrave Macmillan.

MELO, Cristina. T.V. (1999) Cartas à redação: uma abordagem discursiva. Tese de Doutorado. Campinas: UNICAMP.

MEYER, Philip (2004). The Vanishing Newspaper: saving journalism in the information age. Columbia: University of Missouri Press. 
MOSCA, Lineide do Lago Salvador (1990). Subjetividade no editorial: uma análise retóricoargumentativa da adjetivação. Tese de doutorado. São Paulo, Universidade de São Paulo, Faculdade de Filosofia, Letras e Ciências Humanas

OESTERREICHER, Wulf (1997). Lo hablado en lo escrito. Reflexiones metodológicas y aproximación a una tipología. In: T. Kotschi/ W. Oesterreicher/ K. Zimmermann (eds.) El Español hablado y la cultura oral en España y Hispanoamérica. Frankfurt am Main: Vervuert/ Madrid: Hiberoamericana, p. 317-340.

OESTERREICHER, Wulf (2001). La "recontextualización” de los géneros medievales como tarea hermenéutica. In: Daniel Jacob/ Johannes Kabatek (eds.). Lengua medieval y tradiciones discursivas en la Peninsula Ibérica. Frankfurt am Main: Vervuert/ Madrid: Iberoamericana, p.199-231.

OESTERREICHER, Wulf (2002). Autonomización del texto y recontextualización. Dos problemas fundamentales en las ciencias del texto. In: Eduardo Hopkins Rodríguez (Editor). Homenaje Luis Jaime Cisneros. Lima: Pontificia Universidad Católica del Perú, vol. I. pp. 343-387.

OLIVEIRA, João Gualberto de (1978). Nascimento da Imprensa Paulista. São Paulo: Gráfica Sangirard.

PERELMAN, Chaïm.; OLBRECHTS-TYTECA, Lucie (1996). O tratado da argumentação: a nova retórica. São Paulo: Martins Fontes.

PERUZZO, Cicilia M. Krohling (2006) Mídia local e suas interfaces com a mídia comunitária no Brasil. Anuário internacional de comunicação lusófona 2006, vol. 4, n. 1, pp. 141-169. Disponível em:

http://revcom2.portcom.intercom.org.br/index.php/anuariolusofono/issue/view/107

RIZZINI, Carlos (1968). O jornalismo antes da tipografia. São Paulo: Nacional.

RIZZINI, Carlos (1988). O livro, o jornal e a tipografia no Brasil (1500-1822). São Paulo: Imesp. SANT'ANNA, Lourival. (2008) O destino do jornal: a Folha de S. Paulo, O Globo e o Estado de S. Paulo na sociedade da informação. Rio de Janeiro: Record.

SANTANA, Denise Maria Rodrigues de. Substantivo e formalismo vocabular no gênero "editorial" (2003). In: PAULIUKONIS, Maria Aparecida Lino e GAVAZZI, Sigrid (orgs.) Texto e discurso: mídia, literatura e ensino. Rio de Janeiro: Lucerna, p. 110-119.

SCHLIEBEN-LANGE, Brigitte (1993 [1983]). História do falar e história da linguística. Tradução de Fernando Tarallo et al.. Campinas: EDUNICAMP.

SCHMIDT-RIESE, Roland (2002). Glosando las confesiones de los hermanos Ávila. Discurso e identidad en la Nueva España a finales del siglo XVI. Lexis, vol. XXVI (1): 3-78.

SILVA, Jane Quintiliano Guimarães (2002). Um estudo sobre o gênero carta pessoal: das práticas comunicativas aos indícios de intertextualidade na escrita de texto. Tese de Doutoramento. Belo Horizonte, Universidade Federal de Minas Gerais.

SILVA, Vera Lúcia Paredes (1997) Variações tipológicas no gênero textual carta. In: KOCH, Ingedore G. V. e BARROS, Kazue S. Monteiro de (orgs.). Tópicos em Linguística de Texto e Análise da Conversação. Natal: EDUFRN, p. 118-124.

SIMÕES, José da Silva (2007). Sintaticização, discursivização e semanticização das orações de gerúndio no português-brasileiro. São Paulo: Universidade de São Paulo, Tese de Doutoramento, Programa de Pós-Graduação em Filologia e Língua Portuguesa - FFLCH.

SODRÉ, Nelson Werneck (1999). História da imprensa no Brasil. 4.ed. Rio de Janeiro: Mauad. 
SWALES, John (1990). Genre analysis. Cambridge: Cambridge University Press. Vervuert/ Madrid: Iberoamericana, p. 97-132.

VAN DIJK, T. A. (2008). Discurso e poder. São Paulo: Contexto.

VELOSO, Mariza; MADEIRA, Angélica (2000). Leituras brasileiras: itinerários no pensamento social e na literatura. Rio de Janeiro: Paz e Terra.

VIOLI, Patrizia (1987) La intimidad de la ausencia: formas de la estructura epistolar. Revista de Occidente, 68, p. 87-99.

ZAVAM, Aurea S. (2009). Historiando uma tradição discursiva: a construção da autoria institucional em editoriais de jornais cearenses. Revista Encontros de Vista. 3.ed., jan./jun., p.1-16.

Recebido em: 05/dez./2010

Aprovado em: 05/mai./2011 